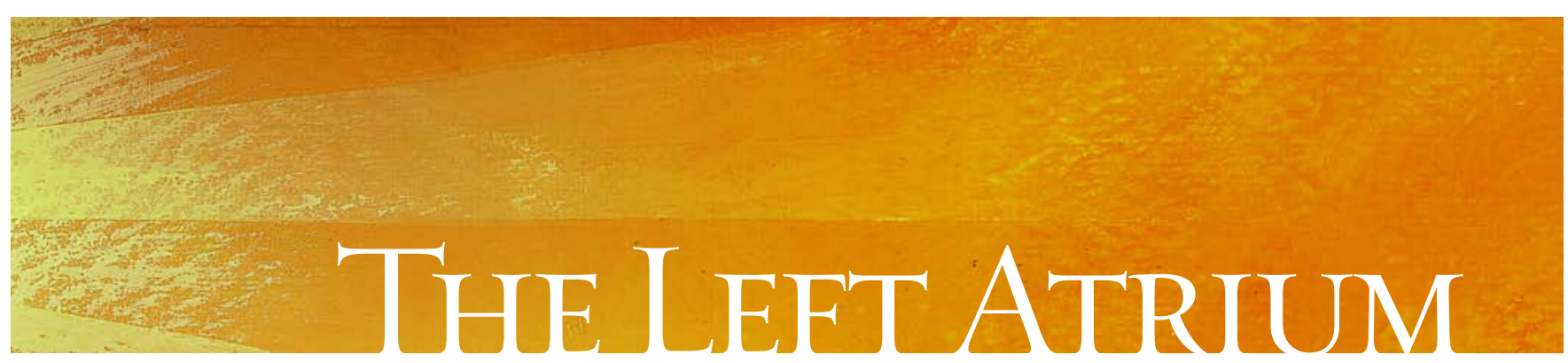

Room for a view

\title{
North
}

I am driving North. My friend and I had been residents together, both older, both in our second careers. He had moved North while I stayed in the city.

I am apprehensive. My belly is huge, eight and a half months of new life jabbing at my abdomen. My husband is with me and is unusually quiet. How will he react, I wonder. He has never met my friend, although I had spoken of him often. What will it be like for them to meet now, in this circumstance, saying hello for the first time, knowing they will never meet again.

I have never met my friend's wife. What will I say to her? "It's been great knowing him, he was such a wonderful doctor"? His death is imminent. I want to make this trip but I dread going to a house of death. Will it affect my child? What are we going to talk about - the good old days? I get lost several times, take wrong turns, my normally keen sense of direction failing me. A delaying tactic no doubt.

We arrive.

Snow is falling heavily and the countryside is blanketed with a heavy silence. But strangely, it's a warm blanket, I feel enveloped and taken care of by it.

A young man, recently out of adolescence, opens the door. He greets us, smiling calmly, calls his Mom and goes out to shovel snow. We are left alone for a few moments. A huge Christmas \& tree fills the living room. There is a strange calm here, I don't understand it. Where is the wailing and weeping, the shaking of fists at the heavens, ranting against God and life for this cruel turn of events?

His wife comes to greet us, calm, soft spoken. She ushers us into the bedroom where he spends most of his time now. He has changed but I'm not shocked. A once somewhat overweight robust man, he is now thin, skin and bones. Oddly, the chemo made his hair grow back thicker and darker so in some ways he looks younger. He's in pain but refuses to take more meds than absolutely necessary, not wanting a single second of his time with his precious family to be obscured.

I am amazed at how quickly time passes. There is no tension, no searching for words as I had feared. We talk about his death, the provision he has made for his family. They are prepared and death does not frighten them. I wonder about denial but conclude that this is not the case. He speaks of his children with pride and hope.

His wife goes to prepare dinner. My husband takes the dog for a walk and I am alone with my friend. He drifts in and out of sleep. There is absolute silence. A clump of snow falls lazily from the branch that strokes the window. I can't recall if there was a sun that day but if so it is setting, casting an orangepink glow over the frozen lake outside. The light in the room is fading. My belly is still. Occasionally he awakens, asks about a colleague, makes a comment, speaks with regret that he didn't get to practise longer, then drifts off again. I don't know how long I sat there. Just under an hour I think.

Serenity. A word seldom used these days, certainly not in psychiatry, my line of work. We all eat dinner in his room. He gives Thanks, for friends and family, for this food, for life. When it is time for us to leave he is sleeping, but he awakens briefly to say farewell.

I did not attend his funeral, being so close to giving birth. A memorial service was planned in the city but I was in labour. I did not cry over his death, although I mourned it in my own way. My colleagues may accuse me of denial, of being unable to reconcile death with the impending birth of my child. I disagree. I have mourned other losses with violent grief. I cannot deny death. My friend's acceptance of death, his family's acceptance, their ability to look death in the face and their faith in what lay ahead made it seem like he had taken a step forward. He has moved on. One day I'll make the trip and catch up with him again.

I hope it snows.

\section{Eileen Sloan}

Mt. Sinai Hospital

Toronto, Ont. 